\title{
Verifying personal relationship to the past
}

\section{Elina Salminen: Monta kuvaa menneisyydestä. Etnologinen tutkimus museokokoelmien yksity- isyydestä ja julkisuudesta. Diss. with a summa- ry in English (Images of the Past. An ethnologi- cal study of the privacy and publicity of mu- seum collections). Department of Art and Cul- ture Studies, University of Jyväskylä 2011. Online. ${ }^{1}$}

When I read Elina Salminen's doctoral thesis I found myself many times thinking, why she finds the relationship of the museums and the private collections called museums so very problematic. In cases examined by her, several museum professionals considered these private collections to be of a minor significance from the standpoint of the institutional museums. On the other hand, interviewed private collectors whose collections have been accepted in a professional museum collection did not deal the professional principles of e.g. the permanence of collections. This seems not to be a severe confrontation anyway.

More irritatingly, in the last hundred years museum people in Finland have recurrently trivialized collections of museums kept by local societies as scrap heaps. They have patronized "laymen's" museums. Professionals in museums have at times not realized what a small part their work is of all the caring and interpretative activities dealing with the things inherited from the past. The discrepancy is topical as well. In Museokello published by the Pirkanmaa Provincial Museum 2011, Kimmo Levä debates useless museums. One has to attempt not to blend the roles and tasks of professional and amateur museums, he writes. The number of the latter is twice of that of the former. ${ }^{2}$ Local societies take care of the main number of amateur museums in Finland on a voluntary basis. "Amateur" refers to the missing academic education and museum practice required to be a museum professional. Often these amateurs have been retired teachers or other public servants and local people who are interested to save memories of the world they know well. Levä provocatively claims that the amateur museum matters only to those who have it as a hobby and thus do the voluntary work that has to be done. If they lack, the museum is not needed and can go. Pirkanmaa Provincial Museum, in the same volume, presents another picture. ${ }^{3}$ The museum invests even in the nonprofessional museums in its area of operation, like other provincial museums do. They don't underline the differences between professional and non-professional museums but stress cooperation. The voluntarily kept local heritage museums are important actors in the field of local culture and regional museum work. It is not at all socially indifferent whether they bloom or not. In the era of consolidation of municipalities the situation is worst for unprofessional local heritage museums owned by municipalities and without a voluntary local society taking care of them. Their collections are maybe preserved but many museums will be closed, indeed, when several municipalities are conjoined. The idea of the permanence of museums is rapidly changing in Finland.

Salminen has started her research in the middle of the 1990's. At that time discussion of the massive and unplanned growth of museum collections and their often doubtful quality were highlighted. Collection politics, classification by quality and acceptation of deaccession were demanded. Keeping of collections was expensive because of the ever higher 
158 rents of the premises and the better quality demanded of the store rooms. It was not enough to criticize the collections of professional museums. The collections of the local heritage museums were doomed as uniform and thus most of the material useless. But useless for whom?

In this atmosphere Elina Salminen found her duty: to highlight in the academic discussion the everyday (underestimated) ways to save and represent the past. Some starting points for the work can be traced back to Ari Pöyhtäri's licentiate thesis: Keräilystä kokoelmaan (in English From Collecting to Collection) which brings out private museums as interesting "nightmares" of "museum people". From the same source Salminen got her interest in Walter Bemnjamin's "positive countertype of the collector". This utopistic creature releases artifacts from the sphere of consumption, and their benefit are replaced by enchantment. A historical fragment opens itself for new ways of reading and can, thus, open depressed pasts which otherwise could remain hidden. Pöyhtäri supposes that this creature can possibly be found in private museums. Salminen tries to test this but does not find the type in there.

The study is about museum collections and their keepers. Salminen does not ask what a museum collection is. She asks: Do you have a museum collection? Accordingly, all collections called museum by the owner are museums. Why the collection is called museum by the private owner was not asked, either. There are lots and lots of collections not called museums in Finland. We can maybe after reading the thesis conclude that collections connected to traditional rural means of livelihood and kept in a building connected to these, are most often called museums. They have often their own museum building, a granary, where the collection can be ordered and presented.

The main study material is made up of interviews and answers to inquiries plus presentations and programs in museums' home pages. The inquiry "Do you have a museum?" published in an regional newspaper 1996 and the answers to the question was the starting point. Salminen inquired for private museums and collections for her doctoral thesis in ethnography. She received what she asked for: Many collections called museums and telling about rural folk life and some special collections like a radio museum and a war museum. There were no collections of natural specimens and few collections connected to art. Salminen notes that her research process and research materials closely rely on each other. In this case the research material seems to be collected by calling and the cases are those who answered. Some of those who answered were visited and interviewed and their collection was acquainted with. In a later phase when new research problems had raised the museum owners were not approached again with new questions. Many informants had already passed away.

Thus, the material of museum collections owned by private people was gathered by Salminen mostly in the 1990s. Research problems took form only gradually. In the next decade, she took cases of professional museums as a point of comparison. That time, professional museums were already in a new phase defining their collection policies, digitalizing their collections, representing them in internet - and writing museum histories. Salminen's private and public museums and the research materials of them seem to be far from each other. As connecting links, four cases are included where either a private thematically 
narrow collection has become a part of a professional museum (2 cases) and where an individual private collection has become the basis of a new museum, professional or approaching professionalism (2 cases). Additionally, one private museum founded in connection of a tourism resort was included.

Privacy and publicity lie in the core of Salminen's study even if Salminen does not proceed very long with the analysis of the concepts. Instead, in compliance with her rescue duty, she goes into a private collector's relationship to the past. Their collections are, without doubt, private but in the same time they can be open to visitors and easy to approach. As Salminen observes, they are not very individual, even if the owners feel they are. Similar objects and groupings can also be found in many public museums. Salminen treats her private informants and their collections anonymously and the collections are in general not connected to any social locality or the everyday life of the collectors. Thus, the relationship to the past can only be viewed through the collection without a wider social context. Collections are anonymous, somewhere in Finland. There is no claim that they would represent private collections called museums in Finland generally. Still we can understand that this kind of collections is a common phenomenon.

Salminen describes her method of study so that she tries to find themes in the collected study material, discuss these and classify them in a theoretical frame.

Collections called museums by the individual owner Salminen calls private museums. She calls professional museumspublic museums and collectively the museum institution. The local heritage museums taken care by local societies make, according to Salminen, up a large "gray area" between these extremes. They are closer to the museum institution than to the private museums, because they have a formal status which enables them to receive subvention from state. Salminen divides all museums to general museums and special museums on the basis of the width of the theme of the museum.

According to Salminen, in the concept of museum culminate longing to the past and need to classify and control over the life through the collection. The private collector builds his/her own identity, the public museum the past and identity of the community. She tries to outline parallel pictures of her private and public museum collections.

She discusses the public museums on the basis of publications, papers on collection policies and interviews of museum personal (director and curator) and tries to find common rules of creating images of the past. She finds the principles of publicity, social relevance and orderliness in collecting. A provincial museum can seek a generality, typicality, significance and regionality, and a single object has its relevance as part of the collection. According to Salminen, cultural, not individual narratives of the past are presented. Only with the customer an individual point of view comes up. Salminen does not discuss the role of individual actors in professional museums, differences between e.g. small and large museums with different kinds of responsibilities, or messiness, challenges and negotiations of everyday work.

In a private museum Salminen can distinguish two ways of representation: In special museums the phenomenon is structured as a trajectory on a timeline, stressing the older part of it. In a general museum the story is typically told in the outbuilding of a farmhouse 
160 or in a former farm house and it is about the past of one's own kin or of the farm in question, as a part of the farm. The collection has been saved for the generations to come. The story is nostalgic and about a past which is one's own. The owner is connected with the past by the collection in the midst of the present.

Salminen's impression is that the museum institution collects and documents systematically and defines the denotations of the objects by thesauri and Outline of Cultural Materials. The owners of private museums do not care whereon his/her classification rests. The objects merely "are" in the memory of the owner, the classification becomes apparent in how the objects have been grouped and arranged in the museum. Regarding the accessibility, the public museums engage a "showcase distance" and customers experience is visual. Most objects are in store rooms. In a private museum the customer is mostly the owner him/herself, living with the collection, handling the objects and creating sensory interpretations of the past.

The private museums as Salminen uses the concept have no responsibilities towards some "public" or "society". The owners are free to decide what to do with the collection and who may see it. Other museums, even the nonprofessional ones, have many kinds of responsibilities towards customers, owners and the wider society. Salminen sees cultural heritage connected with the public sphere and cultural policies. But what is the heritage in the private sphere, belonging to the everyday domestic life, such as the feeling of belonging to a place? A private collection seems often to strengthen such an experience of belonging. Salminen refers to Regina Bendix and her concepts (cultural) heritage and (cultural) heredity, but not to her third concept hybridity which is linked with (cultural) heritage. Bendix writes: "Heritage demands specialists to restore and preserve it materially [-] Heritage requires facilities for its display, and guards for its protection." Heritage is thus connected with expert institutions like the professional museums and fits with Salminen's thoughts. On the other hand, Salminen has interpreted Bendix's concept of heredity in a strange way: as the private everyday dimension of the past. According to Bendix: "The term heredity connoting noble blood lines slowly expanded to refer to peoples and their cultures, as was typical of the nationalist project sweeping across Europe." By Bendix, heredity has to do with "pure" heredity lines and the care of the purity. Cultural heredity is not about private everyday life and apolitical. Instead it is a highly political concept: it is about cultural purity, and fuels heritage. But heritage can be and is blended, hybride.

One of the central outcomes of the study is the interpretation and description of the private general museum's view of the past: The private general museums and the pasts they represent are about doing: the past is the time, the place and the social connection of doing. The classification or placing of the things in the museum is nostalgic. The past life is conceived as hard but mostly positive. Everything had its place and meaning and the human body got enough motion in everyday hard work, close to nature. Men's works and women's works were easily discerned from each other. The collections illustrate even scarcity. On the other hand, people were skillful and able to prepare and make many kinds of things themselves. These collections were very much wooden: an abundance of wooden artifacts in wooden buildings. In private museums, the artifacts refer to a past time and a past way of life, 
sometimes even to certain persons. The memory of the collector and the keeper of the museum are mediated by his/her telling stories. This memory can vanish with the person and be replaced with another, e.g. a remembrance of the collector himself. The memory can also be mediated as a tradition connected to the objects.

The private general museums refer to a time before industrialization (of farming), before WW II. They rescue past and find what has been lost. The past means original, not altered, not copied. This authenticity is strengthened by marked dates, and marks in wood, manufacture marks of the Arabia faience factory, and the handcraft of the village smith. Their image of the past is rather national romantically about peasant life - like many of the local heritage museums. The collections repeat a model, which is familiar in the local heritage museums now and earlier. The professional museums and the local heritage museums have strongly affected the building up of these private collections, and vice versa. These collectors are far from "the positive countertype of a collector".

Salminen's study and description of the private collections called museums cast delightfully new light on the little examined but usual part of everyday life. There is, however, an imbalance between the study of the private and the public museums. She could have focused more on the private actors and leave the relatively superficial study of the professional museum even more aside. Salminen asks who has the right to found a museum. More actual question would be, who has a possibility to contribute to, what is really taken care of in our (cultural) environment, including the objects that can be collected. It would be of great interest to know more, how the maintainers of the private museums cherish their own cultural environments and representations of the past therein, and why.

\section{NOTES}

1. The doctoral thesis is available at http://dissertations.jyu.fi/studhum/9789513941703.pdf

2. Kimmo Levä: Onko Suomessa turhia museoita? Museokello. Kulttuuriympäristö- ja museouutisia Pirkanmaalta, 2011. Pirkanmaan maakuntamuseo.

3. Miinu Mäkelä, Kompassi näyttää museoon! Museokello. Kulttuuriympäristö- ja museouutisia Pirkanmaalta, 2011. Pirkanmaan maakuntamuseo.

4. Ari Pöyhtäri, Keräilystä kokoelmaan. Sosiologisia ja filosofisia näkökulmia keräilyyn. SoPhi, Yhteiskuntatieteiden, valtio-opin ja filosofian julkaisuja 18. University of Jyväskylä 1996.

5. Walter Benjamin, Der Sammler. In: Hrsg. von Rolf Tiedemann, Walter Benjamin: Gesammelte Schriften. 5. Das Passagen-Werk. Suhrkamp, Frankfurt am Main 1982.

6. Regina Bendix, Heredity, Hybridity and Heritage from One Fin de Siècle to the Next. In: Ed. by Pertti J. Anttonen, Anna-Leena Siikala, Stein R. Mathisen and Leif Magnusson. Folklore, Heritage Politics and Ethnic Diversity. Festschrift for Barbro Klein. Multicultural Centre: Botkyrka 2000.

Sirkku Pihlman, PhD

Opponent of the dissertation

Researcher in Museology, School of History,

Culture and Art Studies, University of Turku, Finland

Address: Museology,

FI -20014 University of Turku

E-mail: sirkku.piblman@utu.fi 